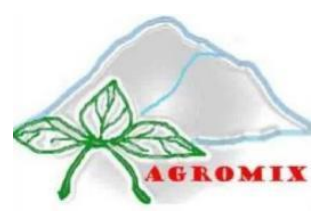

\title{
AGROMIX
}

Jurnal IImiah Fakultas Pertanian, Universitas Yudharta Pasuruan pISSN (Print): 2085-241X; elSSN (Online): 2599-3003

Website: https://jurnal.yudharta.ac.id/v2/index.php/agromix

\section{Identifikasi nilai sikap masyarakat terhadap pengembangan potensi budidaya kepiting bakau (Scylla serrata) di desa Sumberwaru kecamatan Banyuputih kabupaten Situbondo}

Identification of the value of community attitudes towards developing the potential for mangrove crab (Scylla serrata) cultivation in Sumberwaru village, Banyuputih sub-district, Situbondo district

\author{
Sasanti Sihsubekti ${ }^{1}$, Dayang Diah Fidhiani ${ }^{1^{*}}$ \\ ${ }^{1}$ Program Studi Budidaya Perairan, Sekolah Tinggi Ilmu Perikanan, Malang \\ *E-mail korespondensi: d fidh@yahoo.com
}

\section{Article History}

Received : October 20, 2020

Accepted : February 25, 2021

Published : March 30, 2021

Keyword

Attitude Value; Mangrove Crab

Cultivation; Potential

Development

\section{ABSTRACT}

This study aims to identify the value of community attitudes towards the potential of mangrove crab (Scylla serrate) cultivation in Sumberwaru Village, Banyuputih District, Situbondo Regency. The research location was determined purposively (intentionally) in the coastal and coastal areas of Sumberwaru Village, Banyuputih District, Situbondo Regency. Determination of respondents using purposive sampling technique and the number of respondents as many as 55 people. The results showed that the stages of the attitude of the Sumberwaru Village community at the affective, cognitive, and conative stages, which means that from the field conditions, it is known that the value of the Sumberwaru Village community's attitude towards the development of the potential for mangrove crab cultivation is still in the growing stage and requires continuous assistance by more competent parties. so that the national development goals of local potential-based regional development (mangrove crab cultivation) can be achieved optimally.

\section{Riwayat Artikel}

Dikirim : 20 Oktober 2020

Disetujui : 25 Pebruari 2021

Diterbitkan : 30 Maret 2021

\section{Kata Kunci}

Nilai Sikap; Pengembangan

Potensi; Budidaya Kepiting

Bakau

\section{ABSTRAK}

Penelitian ini bertujuan mengidentifikasi nilai sikap masyarakat terhadap potensi budidaya Kepiting bakau (Scylla serrate) di Desa Sumberwaru, Kecamatan Banyuputih, Kabupaten Situbondo. Lokasi penelitian ditentukan secara purposive (sengaja) di kawasan pesisir dan pantai Desa Sumberwaru, Kecamatan Banyuputih, Kabupaten Situbondo. Penentuan responden menggunakan teknik purposive sampling dan jumlah responden sebanyak 55 orang. Hasil penelitian menunjukkan bahwa tahapan nilai sikap masyarakat Desa Sumberwaru pada tahap afeksi, kognitif dan konasi, yang berarti dari kondisi lapang diketahui nilai sikap masyarakat Desa Sumberwaru terhadap pengembangan potensi budidaya kepiting bakau masih dalam tahap tumbuh dan membutuhkan pendampingan yang berkelanjutan oleh pihak yang lebih berkompeten, agar tujuan pembangunan nasional dari pengembangan wilayah berbasis potensi lokal (budidaya kepiting bakau) bisa tercapai dengan optimal.

Sitasi: Sinsubekti, S., \& Fidhiani, D. D. (2021). Identifikasi nilai sikap masyarakat terhadap pengembangan potensi budidaya kepiting bakau (Scylla serrata) di desa Sumberwaru kecamatan Banyuputih kabupaten Situbondo. Agromix, 12(1), 47-54. https://doi.org/10.35891/agx.v12i1.2429

\section{PENDAHULUAN}

Berbagai jenis kepiting dapat dijumpai di perairan Indonesia. Diperkirakan terdapat 2500 jenis spesies di Indonesia dari total 4500 spesies yang terdapat di seluruh dunia. Namun tidak semuanya bisa dikonsumsi, ada empat jenis kepiting yang umumnya dikonsumsi. Salah satunya adalah kepiting bakau (Scylla serrata) yang merupakan jenis kepiting paling populer sebagai bahan makanan dan mempunyai harga yang cukup mahal. Harga kepiting Scylla serrata yang tinggi dan permintaan pasar yang cukup besar menjadikan kepiting jenis ini terancam punah akibat over eksploitasi melalui aktivitas penangkapan nelayan. Sehingga dengan adanya hal ini pemerintah mengeluarkan regulasi pelarangan penangkapan pada ukuran tertentu melalui Peraturan Menteri Nomor 01 tahun 2015, guna menghindari kepunahan spesies, pelarangan ini pada sisi yang lain berdampak pada pendapatan nelayan yang biasa menangkap kepiting. 
Kepiting bakau (Scylla sp.) ditemukan melimpah di ekosistem mangrove (Leoville dkk., 2021) dan dipengaruhi oleh kondisi ekosistem mangrove dan lingkungan (Kusuma dkk., 2021). Spesies ini berperan penting pada karakteristik sedimen serta kandungan bahan organik yang ada (Widyastuti, 2016). Kelimpahan kepiting bakau dipengaruhi oleh kondisi ekosistem mangrove. Tingkat kerapatan mangrove yang tinggi dapat menyediakan jumlah makanan yang cukup (Gita \& Sudarmadji, 2015). Selain itu, parameter fisika-kimia lingkungan seperti suhu, salinitas, pH (Rizaldi dan Utami, 2015), dan jenis substrat juga akan mempengaruhi keberadaan dan kelimpahan kepiting bakau (Avianto dkk., 2013). Pertumbuhan terbaik kepiting bakau berada pada kisaran salinitas sebesar 10-20\%o (Ruscoe dkk., 2014) dan dapat menoleransi salinitas pada kisaran 2-40 \%o (La Sara dkk., 2014).

Ketergantungan pasar kepiting terhadap hasil tangkapan juga terjadi di Kabupaten Situbondo, berdasarkan Laporan Tahunan Dinas Keluatan dan Perikanan Kabupaten Situbondo tahun 2013, 2014 dan 2015, produksi kepiting bakau (Scylla serrata) masih didominasi hasil tangkapan, sementara hasil budidaya tambak masih kecil. Kepiting bakau adalah salah satu potensi yang ada di hutan mangrove dan masih banyak yang belum mengetahui (Zulfiqri dkk., 2020), mempunyai nilai ekonomis penting serta mempunyai harga yang mahal (Hia \& Hendrarto, 2013) dan meningkatkan pendapatan masyarakat yang tinggal di sekitar kawasan mangrove. Scylla serrata merupakan komoditas ekspor di samping rajungan (Portunus pelagicus). Bila rajungan mempunyai nilai ekonomis penting sebagai daging dalam kaleng atau dalam keadaan beku, maka kepiting bakau dapat dipasarkan dalam keadaan hidup karena lebih tahan hidup di luar air (Syahrera dkk., 2016).

Belum adanya estimasi kebutuhan pasar secara pasti terhadap produksi kepiting bakau Scylla serrta di Situbondo, hanya saja dari produksi yang ada selama ini, para pengepul masih sering kali kekurangan stok kepiting bakau, baik stok kebutuhan bibit untuk usaha penggemukan maupun konsumsi. Fenomena over ekspolitasi akibat tingginya permintaan pasar kepiting, sebenarnya dapat tertanggulangi oleh optimalisasi diversifikasi usaha nelayan, dimana budidaya kepiting bakau sebagai salah satu alternatif usaha, sehingga nelayan penangkap kepiting tidak selalu bergantung pada hasil tangkapan alam. Pemenuhan permintaan pasar akan kepiting bakau melalui budidaya tidak hanya berdampak pada terpenuhinya permintaan pasar serta keuntungan finansial nelayan, upaya perlindungan dan pelestarian jenis kepiting yang mulai punah berikut ekosistemnya secara otomatis akan menjadi agenda bersama pelaku budidaya dan pemerintah. Degradasi ekosistem mangrove dan eksploitasi berlebihan yang banyak terjadi di perairan Indonesia telah mengakibatkan penurunan pada populasi kepiting bakau (Sangari dan Tolon, 2015).

Desa Sumberwaru merupakan salah satu desa pantai yang secara adiministratif berada di Kecamatan Banyuputih Kabupaten Situbondo. Desa yang menjadi desa penyanggah Taman Nasional Baluran ini terbagi menjadi 5 dusun ; Cotek, Krajan, Belangguan, Sidomulyo dan Merak. Desa ini memiliki kawasan hutan lindung $2.070 \mathrm{Ha}$, hutan produksi $7.464,900$ dan hutan konservasi $524.250 \mathrm{Ha} / \mathrm{m} 2$. Berdasarkan hasil inventarisasi Dinas Kelautan dan Perikanan, dari luas hutan yang berada di Desa Sumberwaru, terdapat hutan bakau seluas $7.000 .000 \mathrm{~m} 2$ dengan jenis Api-api. Nelayan desa Sumberwaru masih sering kali mendapat tangkapan kepiting bakau Scylla serrata dalam jumlah kecil. Selama melakukan penelitian, penulis menemukan nelayan yang berhasil menangkap kepiting dengan berat 5 ons satu ekor dengan kondisi matang gonad, ukuran ini merupakan ukuran yang cukup untuk pengadaan induk pada usaha pembenihan. Dimana jumlah rata-rata perbulan hasil tangkapan kepiting di perairan Sumberwaru berkisar 15 sampai $20 \mathrm{~kg}$ per bulan.

Menyikapi situasi seperti di atas, dapat dinilai jika kawasan hutan bakau dan pantai Desa Sumberwaru memiliki potensi untuk pengembangan budidaya Kepiting Bakau (Scylla serrata) yang tentunya akan mudah tercapai jika didukung dengan sikap masyarakat lokalnya dalam pengembangan wilayah untuk budidaya Kepiting Bakau (Scylla serrata). Sikap masyarakat dinilai dalam 3 (tiga) aspek yakni: 1. Aspek Kognitif yang meliputi: Tingkat Pendidikan, Kepahaman Masyarakat Terhadap Fungsi Hutan Bakau dan perolehan informasi tentang pemanfaatan hutan bakau sebagai lahan budidaya kepiting bakau; 2. Aspek Afektif yang meliputi: Ketertarikan responden pada usaha budidaya Kepiting Bakau (Scylla serrata) dan 3. Aspek Konatif meliputi: keterlibatan masyarakat dalam pengelolaan sumberdaya hutan bakau. Penelitian ini bertujuan untuk mengidentifikasi nilai sikap masyarakat terhadap potensi pengembangan budidaya kepiting bakau di Desa Sumberwaru, Kecamatan bayuputih, Kabupaten Situbondo.

\section{METODE}

Lokasi penelitian ditentukan secara purposive (sengaja) di kawasan pesisir dan pantai Desa Sumberwaru, Kecamatan Banyuputih, Kabupaten Situbondo. Menilik wilayah ini memiliki luasan hutan mangrove $7.000 .000 \mathrm{~m}^{2}$ dengan struktur lingkungan yang berpotensi untuk dilakukan pengembangan budidaya kepiting bakau. Selain kondisi sumberdaya alam yang mendukung, sekitar $60 \%$ penduduknya bermata pencaharian sebagai petani, petambak/ buruh tani, buruh tambak dan nelayan. Sehingga dengan keadaan yang demikian menarik untuk dilakukan suatu kajian mengenai nilai sikap masyarakat terhadap pengembangan potensi budidaya kepiting bakau di Desa Sumberwaru, Kecamatan Bayuputih, Kabupaten Situbondo.

Pendekatan penelitian yang digunakan adalah gabungan dari pendekatan penelitian kualitatif dan kuantitatif dengan menggunakan metode deskriptif. Menurut Santoso (2008), penelitian kuantitatif dengan menggunakan format deskriptif bertujuan untuk menjelaskan, meringkaskan berbagai kondisi, situasi atau berbagai variabel yang timbul di 
masyarakat. Penelitian ini merupakan tipe penelitian deskriptif studi kasus, yang mana untuk mendapatkan sintesis hasil analisis nilai sikap meliputi aspek Afektif, Kognitif dan Konatif dilakukan pembandingan dengan tahapan tingkat keberdayaan masyarakat (Sulistyani, 2004), sebagai berikut:

Tabel 1. Penilaian tahapan tingkat keberdayaan/ nilai sikap masyarakat

\begin{tabular}{|c|c|c|c|c|}
\hline No & Tahapan Afektif & Tahapan Kognitif & Tahapan Konatif & Skor Nilai \\
\hline 1. & $\begin{array}{l}\text { Belum merasa sadar dan } \\
\text { peduli }\end{array}$ & $\begin{array}{l}\text { Belum memiliki wawasan } \\
\text { pengetahuan }\end{array}$ & $\begin{array}{l}\text { Tidak } \\
\text { membangun }\end{array}$ & $1,00-2,00$ \\
\hline 2. & $\begin{array}{l}\text { Tumbuh rasa kesadaran dan } \\
\text { kepedulian }\end{array}$ & $\begin{array}{l}\text { Menguasai pengetahuan } \\
\text { dasar }\end{array}$ & $\begin{array}{l}\text { Bersedia terlibat dalam } \\
\text { pembangunan }\end{array}$ & $2,01-4,00$ \\
\hline 3. & $\begin{array}{l}\text { Memupuk semangat } \\
\text { kesadaran dan kepedulian }\end{array}$ & $\begin{array}{l}\text { Mengembangkan } \\
\text { pengetahuan dasar }\end{array}$ & $\begin{array}{l}\text { Berinisiatif untuk mengambil } \\
\text { peran dalam pembangunan }\end{array}$ & $3,01-4,00$ \\
\hline 4. & $\begin{array}{l}\text { Merasa membutuhkan } \\
\text { kemandirian }\end{array}$ & $\begin{array}{l}\text { Mendalami pengetahuan } \\
\text { pada tingkat lebih tinggi }\end{array}$ & $\begin{array}{l}\text { Berposisi secara mandiri } \\
\text { untuk membangun diri dan } \\
\text { lingkungan }\end{array}$ & $4,01-5,00$ \\
\hline
\end{tabular}

Analisis tingkat sikap (kondisi afektif, kognitif dan konatif) masyarakat Desa Sumberwaru terhadap pengembangan potensi sumberdaya budidaya kepiting bakau menggunakan teknik analisis kualitatif secara deskriptif. Teknik analisis kualitatif merupakan teknik analisis yang mentransformasikan data mentah ke dalam bentuk data yang mudah dimengerti dan ditafsirkan, serta menyusun dan menyajikan data menjadi informasi yang jelas. Jumlah responden ada 55 orang yang terdiri dari pedagang ikan, nelayan budidaya dan nelayan penangkap. Penentuan responden menggunakan teknik purposive sampling .

\section{HASIL DAN PEMBAHASAN}

\section{Potensi hutan bakau desa Sumberwaru}

Hutan bakau merupakan salah satu potensi utama ekosistem yang berada di pesisir pantai Indonesia dengan luas sebesar 3.735.250 hektare (Haris, 2014). Fungsi dari hutan bakau adalah menyimpan kekayaan spesies dan menyediakan berbagai layanan dan jasa ekosistem yang terdiri dari spesies flora dan fauna (Mahfud dkk., 2017). Salah satu spesies fauna perairan/akuatik yang ada di ekosistem hutan bakau adalah kepiting (Lose dkk., 2015; Putriningtias dkk., 2019). Dari tempat ini biasanya para pengumpul kepiting melakukan penangkapan kepiting bakau dan kemudian menjualnya kepada para pembudidaya untuk dipelihara lebih lanjut hingga moulting dan dilakukan pemanenan. Dengan demikian maka keberadaan hutan bakau (hutan mangrove) merupakan kunci keberlangsungan budidaya kepiting.

Namun demikian, hutan bakau di perairan desa Sumberwaru mengalami kerusakan sangat parah yang diakibatkan oleh konversi lahan pesisir maupun penebangan liar. Kondisi hutan bakau di perairan Sumberwaru di luar kawasan Taman Nasional Baluran nyaris tidak tersisa, hanya tinggal beberapa pohon yang terletak di bekas tambak udang milik PT. Bonar. Upaya penanaman kembali (reforestasi) hutan bakau pernah dilakukan, dana reforestasi berasal dari CSR tambak, akan tetapi upaya penanaman itu tidak ditindak lanjuti proses pemeliharaan yang baik. Sementara itu, data Dinas Kelautan dan Perikanan Kabupaten Situbondo, menyebutkan bahwa di Desa Sumberwaru terdapat hutan bakau seluas $70 \mathrm{Ha}$ yang terdiri jenis Rhizophora spp, Avecinnia Spp, Sonneratia spp. Data itu adalah data hutan konservasi yang dikelola oleh Taman Nasional Baluran, dimana keberadaan hutan bakau ini tertutup untuk usaha budidaya komersial. Tidak adanya hutan bakau di lokasi penelitian bukan berarti kepiting bakau Scylla serrata tidak ditemukan di lokasi ini, keberadaan hutan bakau di wilayah kepemangkuan Taman Nasional Baluran yang dekat dengan lokasi penelitian, berkontribusi positif terhadap keberadaan kepiting bakau Scylla serrata di lokasi penelitian. Parni dkk., (2020) menyatakan bahwa hutan mangrove merupakan salah satu ekosistem pesisir yang berperan penting dalam mendukung kehidupan biota laut, sehingga menurut Wijaya dan Yulianda (2017) diperlukan upaya pengelolaan berkelanjutan dengan melibatkan masyarakat lokal, agar kelestarian ekosistem hutan mangrove tetap terjaga serta. Rahman dan Pansyah (2019), kelestarian hutan mangrove dapat memberikan peluang ekonomi yang sangat besar kepada masyarakat pesisir melalui budidaya kepiting bakau.

Nelayan masih sering kali mendapat tangkapan kepiting bakau Scylla serrata dalam jumlah kecil. Selama melakukan penelitian, penulis menemukan nelayan yang berhasil menangkap kepiting dengan berat 5 ons satu ekor dengan kondisi matang gonad, ukuran ini merupakan ukuran yang cukup untuk pengadaan induk pada usaha pembenihan. Menurut beberapa responden, jumlah rata-rata perbulan hasil tangkapan kepiting di perairan Sumberwaru berkisar 15 sampai $20 \mathrm{~kg}$ per bulan.

Menyikapi situasi seperti di atas, individu nelayan maupun perusahaan yang akan melakukan usaha budidaya kepiting bakau di perairan Sumberwaru bisa melakukan pengadaan benih melalui usaha pembenihan atau membeli bibit dari luar desa. 


\section{Potensi budidaya kepiting bakau di perairan pantai Sumberwaru}

Perairan yang potensial menjadi lahan budidaya kepiting bakau adalah lahan yang secara ekologis ideal. Semakin rapat tanaman bakau maka semakin baik kanopi yang dapat melindungi flora dan fauna di bawahnya serta dapat menjaga kondisi substrat tanah dan bahan organik di daerah tersebut, khususnya kepiting bakau (Pambudi dkk., 2019). Rangka (2007) menyebutkan, lokasi ideal untuk kepiting bakau memiliki tekstur tanah liat berpasir, liat berlempung, kualitas air sesuai dengan parameter fisik dan kimia, ketersediaan stok pakan terjamin dan secara sosial mendukung.

Di Perairan Pantai Sumberwaru dinilai sesuai dengan tipe-tipe lahan yang bisa dijadikan tempat budidaya kepiting bakau, yaitu terdapatnya lahan tambak dimana pada lahan tambak dapat digunakan berbagai teknologi wadah pemeliharaan mulai dari jaring tancap, karamba jaring apung maupun kurungan. Hal ini bisa terlihat di sepanjang pantai Sumberwaru terdapat areal tambak seluas $86 \mathrm{Ha}$, dari luas areal tambak ini, yang berpotensi dimanfaatkan untuk budidaya kepiting bakau sekitar $20 \mathrm{Ha}$, selebihnya telah digunakan untuk budidaya sidat dan udang. Selain itu, potensi budidaya muara sungai dan perairan pantai dengan tekstur tanah pasir berlumpur dengan panjang dan lebar $500 \mathrm{~m}$ x $500 \mathrm{~m}$ atau $25 \mathrm{Ha}$ yang diukur dari batas garis hutan bakau. Sehingga total potensi lahan budidaya kepiting bakau di perairan pantai Sumberwaru seluas $45 \mathrm{Ha}$.

Kemudian perairan pantai dengan kedalaman 10-15 meter, pada tipe lahan seperti ini teknologi yang cocok adalah keramba jaring apung. Berikutnya adalah pantai dengan kedalaman 1-4 meter dengan pasang surut tinggi dan kondisi pasir berlumpur, tipe lahan ini pada saat air laut surut masih tersisa genangan air sekitar $10-25 \mathrm{~cm}$, pada tipe lahan ini cocok menggunakan teknologi jaring tancap atau model kurungan. Selanjutnya muara dan sungai yang masih terkena pengaruh pasang surut air laut. Bahkan beberapa nelayan mengatakan bahwa kepiting bakau bisa dipelihara di air tawar. Hal ini berdasarkan pada pengalaman nelayan mendapat tangkapan kepiting.

Luasan potensi lahan budidaya berikut padat tebarnya, secara sosial ekonomi berdampak pada penyerapan tenaga kerja. Laporan penelitian Bank Indonesia Tahun 2011 menginformasikan bahwa usaha budidaya kepiting soka skala mikro dan kecil dapat menyerap tenaga kerja langsung 3-4 orang per Ha tambak. Dengan demikian, jika luasan potensi lahan budidaya kepiting bakau di Sumberwaru dioptimalkan, maka angkatan kerja yang belum atau tidak bekerja di Desa Sumberwaru akan mudah mendapat pekerjaaan, yang pada akhirnya dapat meningkatkan kesejahteraan masyarakat lokal.

Pengelolaan sumberdaya kepiting bakau di perairan Sumberwaru masih terbatas pada penangkapan, baik oleh nelayan lokal maupun nelayan andon dari Kabupaten Probolinggo dan Banyuwangi. Penyebab tidak optimalnya pemanfaatan potensi lahan budidaya dikarenakan orientasi dan pengetahuan masyarakat pada diversifikasi usaha perikanan belum terbangun, khususnya budidaya kepiting bakau.

Di lain sisi, pengusahaan kepiting bakau pada saat ini mengalami perkembangan. Dari sisi pembenihan, Balai Besar Riset Budidaya Laut (BBRBL) Gondol telah berhasil mengembangkan teknologi dan melakukan pembenihan. Teknologi pembesaran dan penggemukan pun juga berkembang, selain budidaya di lahan tambak dan hutan bakau, pembesaran dan penggemukan menggunakan media terpal di darat juga sudah mulai berkembang. Kepiting bakau juga dibudidayakan dengan suatu metode rekayasa masa ganti kulitnya, yang produk akhirnya dikenal sebagai kepiting soka atau kepiting cangkang lunak. Secara ekonomi, hasil analisis Bank Indonesia pada usaha budidadaya kepiting bakau cangkang lunak menyatakan bahwa usaha ini layak dikembangkan (Bank Indonesia, 2011).

Dalam situasi perkembangan teknologi budidaya dan kelayakan usaha seperti di atas, di Desa Sumberwaru belum ada investasi di bidang usaha budidaya kepiting bakau, hal ini bisa ditandai dari hasil angket yang menyatakan $96 \%$ responden menjawab tidak ada investasi budidaya kepiting bakau di wilayahnya. Investasi dalam suatu usaha, tak terkecuali kepiting bakau, akan meningkat bila terdapat situasi permintaan pasar yang tinggi, stabil, berkorelasi positif dengan stok barang serta didukung oleh regulasi yang menjamin keberlanjutan pasar tersebut. Dalam kerangka pengembangan investasi kepiting bakau di Sumberwaru, mengalami kendala regulasi yang berlaku secara nasional.

Perkembangan investasi kepiting dua tahun terakhir di Indonesia cukup terganggu oleh Peraturan Menteri Nomor 01 tahun 2015, PERMEN yang sejatinya dimaksudkan sebagai upaya perlindungan sumberdaya kepiting bakau, dalam Permen ini kepiting bakau bertelur dan ukuran karapas kurang dari $15 \mathrm{~cm}$ dilarang untuk diperjualbelikan, sementara kepiting bakau bertelur sangat diminati oleh konsumen, dengan demikian, regulasi ini berimplikasi negatif terhadap pelaku usaha budidaya penggemukan dan pelaku bisnis kepiting bakau.

Ketergangguan investasi kepiting bakau oleh Peraturan Menteri Nomor 01 tahun 2015 dikarenakan suplay kepiting bakau di tambak-tambak budidaya penggemukan bergantung pada hasil tangkapan. Penyebab ketergantungan ini adalah belum adanya respon pengusaha terhadap keberhasilan teknologi pembenihan kepiting bakau, pengembangan panti-panti pembenihan kepiting bakau masih belum muncul di Indonesia. Dalam konteks dukungan terhadap penguatan investasi kepiting bakau, diperlukan sebuah sistem produksi hulu hilir usaha kepiting bakau, dimana dalam regulasi perlu ada pengecualian terhadap produk kepiting bakau yang dihasilkan dari budidaya.

Menyikapi situasi sebagaimana tergambar di atas, ketertarikan responden pada usaha budidaya kepiting dinilai masih tinggi yakni $84 \%$ responden menyatakan tertarik pada usaha budidaya ini. Namun hal ini kontradiktif dengan kemampuan masyarakat nelayan Sumberwaru dalam budidaya kepiting bakau, dari sisi ada tidaknya kelompok masyarakat nelayan yang memiliki kemampuan dalam budidaya kepiting bakau. Kemampuan yang dimiliki oleh 
sebagian kecil masyarakat nelayan di lokasi penelitian adalah kemampuan memelihara pada tahap penggemukan, parameter kemampuan meliputi teknik pemeliharaan, teknologi wadah pemeliharaan serta perilaku makan kepiting. Kemampuan para nelayan masih sangat memerlukan peningkatan pengetahuan, mulai dari teknik pembenihan, manajemen budidaya, pengendalian penyakit, dan manajemen lingkungan perairan budidaya.

Presentasi angka ketertarikan yang cukup tinggi di tengah ketidakmampuan SDM dipicu oleh gambaran situasi permintaan dan harga pasar yang tinggi, selain itu, secara teknologi, budidaya pembesaran atau penggemukan kepiting bakau dirasa mungkin dilakukan. Berkaca pada usaha budidaya komoditas udang lobster dan kerapu di perairan Sumberwaru, masyarakat nelayan Sumberwaru dalam melakukan budidaya komoditas tersebut berawal stimulasi eksternal, yakni investasi pemodal dan program bantuan pemerintah. Dalam wawancara lebih dalam, nelayan tertarik dan siap melakukan budidaya bila terdapat investor maupun program pemerintah untuk memulai usaha budidaya kepiting bakau. Hal ini disebabkan oleh kondisi keuangan keluarga nelayan yang tidak memungkinkan untuk investasi ini.

Dalam mendukung program budidaya perikanan dan laut, di perairan pantai Sumberwaru sudah terdapat kawasan pantai yang diperuntukkan sebagai lahan budidaya, penetapan kawasan sebagai lahan budidaya membuat usaha budidaya perikanan mendapat kepastian secara hukum. Berdasarkan Peraturan Daerah Kabupaten Situbondo Nomor 9 Tahun 2013 tentang Rencana Tata Ruang Wilayah, terdapat kawasan budidaya perairan payau dan laut, dalam hal ini termasuk perairan pantai Sumberwaru. Dalam pasal 35 huruf a ayat 2 PERDA tersebut di atas menyatakan :

"Budidaya air payau terdapat di Kecamatan Besuki, Mlandingan, Kendit, Suboh, Panarukan, Mangaran, Kapongan, Arjasa , Banyuputih dengan luas areal kurang lebih $1.300 \mathrm{Ha}$ (seribu tiga ratus hektar);"

Selanjutnya pada ayat 3 disebutkan :

"Budidaya air laut yang terdapat di Kecamatan Banyuputih, Jangkar, Arjasa, Kapongan, Mangaran, Panarukan, Kendit, Bungatan, Mlandingan, Suboh, Besuki, dan Banyuglugur seluas 1.826,26 Ha."

Hal ini ditandai dengan sudah adanya usaha budidaya ikan dan udang menggunakan teknologi keramba jaring apung, keramba jaring tancap maupun tambak di kawasan perairan Sumberwaru. Selain sudah adanya regulasi tentang kawasan budidaya di Desa Sumberwaru, potensi pengembangan budidaya kepiting bakau juga bisa terlihat dari aspek pasar. Kepiting telah menjadi komoditas penting, peluang pasar yang cukup besar dengan harga tinggi menyebabkan bisnis kepiting berkembang di beberapa tempat seperti di Sulawesi Selatan, Cilacap, Medan dan lainlain, dengan target pemasaran lokal maupun ekspor. Negara tujuan ekspor antara lain: Jepang, Hongkong, Korea Selatan, Taiwan, Singapura, Malaysia, Australia dan Prancis. Kepiting ekspor sebagai sumber devisa negara sekitar $70 \%$ berasal dari usaha budidaya meliputi pembesaran, penggemukan maupun produksi kepiting bertelur (Rangka, 2007).

Kepiting bakau adalah komoditas ekspor yang menjanjikan oleh karena merupakan salah satu komoditas yang diminati oleh konsumen luar negeri. Dalam angka tercatat bahwa antara tahun 2006 - 2010 kenaikan rata-rata volume ekspor kepiting Indonesia ke negara-negara tujuan ekspor adalah sebesar 3,26\%, sedangkan antara tahun 2019-2010 kenaikan rata-rata volume ekspor tersebut meningkat menjadi 6,47\%. Kenaikan rata-rata nilai ekspor antara tahun 2006-2010 sebesar 12,81\%, sedangkan antara tahun 2009-2010 mengalami peningkatan menjadi 25,49\% (bank Indonesia, 2011).

Hasil penelitian Bank Indonesia (2011), harga kepiting bakau di berbagai daerah di Indonesia cukup bervariasi. Pada tahun 2011, untuk - ukuran 10-12 ekor per Kg, di kota Bengkulu kepiting soka dijual dengan harga Rp.60.000,-, sedangkan di kota Mukomuko pada ukuran tersebut kepiting soka dijual dengan harga Rp.40,000,- hingga Rp/50,000,per kg. Di kota Pemalang kepiting soka ukuran 10-12 dijual dengan harga Rp.45.000,- per Kg, sedangkan di Sulawesi Selatan harga jual kepiting soka untuk ukuran 10-12 sebesar Tp.40,000,- per Kg. Harga pasaran kepiting soka di tingkat suplayer Jakarta pada tahun 2011 berkisar Rp.50,000,- sampai dengan Rp.65.000,-

Pada musim-musim tertentu, harga kepiting melonjak karena permintaan yang meningkat seperti pada perayaan imlek dan lain-lain. Pada saat-saat CB (bentina besar/bertelur, ukuran >200 gram per ekor) dan Rp. 30.000,- untuk LB (Jantan berisi, ukuran >500gram - 1000 gram per ekor). Kepiting cangkang lunak (soka) harganya dua kali lipat lebih tinggi. Di luar negeri, harga kepiting bakau grade CB dapat mencapai 8,40 U\$ - 9,70U\$ per Kg sedangkan LB dihargai 6,10 U\$ - 9,00U\$ per Kg. Ukuran >1000 gram (super crab) harganya 10,5 U\$ per Kg.

Permintaan pasar dan harga kepiting yang cukup tinggi sebagaimana digambarkan di atas, ketersediaan stok kepiting dua tahun terakhir ini mengalami ketidaklancaran akibat penerapan Peraturan Menteri Nomor 01 Tahun 2015 tentang Penangkapan Lobster, Kepiting, dan Rajungan. Dalam peraturan itu disebutkan, berat kepiting soka minimal 150 gram. Kondisi ini sangat menyulitkan karena selera pasar, terutama luar negeri yang menyukai soka ukuran kecil, yakni 60-120 gram. (Prasetya, 2017). Harga kepiting bakau di tingkat nelayan maupun pembudidaya di lokasi penelitian berbeda antara satu pedagang dengan pedagang lain, berkisar antara Rp. 40.000 sampai Rp.70.000 dalam kondisi hidup, dalam kondisi mati harga lebih murah $50 \%$. Di lokasi penelitian, sasaran pasar masih tertuju pada pemenuhan pasar lokal, kebutuhan pasar lokal akan kepiting belum bisa dipenuhi oleh nelayan dan atau pedagang ikan Desa Sumberwaru. Sahamar, seorang pedagang ikan di lokasi penelitian menceritakan bahwa ia belum bisa memenuhi permintaan kepiting bakau untuk suplai rumah makan sekitar Banyuwangi, Situbondo, Surabaya dan Bali. Penyebabnya adalah stok tangkapan nelayan kecil dan aturan tentang ukuran kepiting yang boleh dijual semakin ketat. Menurut responden, rantai pemasaran kepiting bakau terbilang mudah. Dikarenakan pasar lokal sekitar 
Banyuwangi, Situbondo, Bali dan Surabaya siap menerima hasil budidaya. Dimana sampai hari ini permintaan kepiting bakau untuk per harinya berkisar 1 (satu) sampai 2 (dua) Kw. Dikarenakan regulasi tentang penangkapan kepiting ada, maka nelayan kesulitan mendapatkan kepiting, padahal pangsa pasarnya dinilai cukup bagus.

Terdapat dua alur pemasaran kepiting di Sumberwaru, pertama, dari nelayan dijual ke pedagang, ke rumah makan lalu ke konsumen. Kedua, ada yang langsung ke konsumen dengan cara diantar ke rumah konsumen oleh nelayan atau konsumen mendatangi rumah nelayan. Dari dua alur pemasaran ini, nelayan mendapatkan harga yang lebih tinggi dari alur penjualan yang langsung ke konsumen. Selisihnya bisa Rp.20.000 sampai Rp.30.000,- (Wahab, 2017).

\section{Analisis identifikasi nilai sikap masyarakat desa Sumberwaru}

Tabel 2. Penilaian tahapan tingkat keberdayaan/ nilai sikap masyarakat

\begin{tabular}{|c|c|c|c|c|c|c|c|}
\hline No & Tahapan Afektif & $\begin{array}{l}\text { Skor } \\
\text { Nilai } \\
\text { Afektif }\end{array}$ & Tahapan Kognitif & $\begin{array}{l}\text { Skor } \\
\text { Nilai } \\
\text { Kognitif }\end{array}$ & Tahapan Konatif & $\begin{array}{l}\text { Skor } \\
\text { Nilai } \\
\text { Konatifif }\end{array}$ & $\begin{array}{l}\text { Skor } \\
\text { Nilai } \\
\text { Total }\end{array}$ \\
\hline 1. & $\begin{array}{l}\text { Belum merasa sadar } \\
\text { dan peduli } \\
\text { (Belum ada } \\
\text { kesadaran dan peduli } \\
\text { tentang potensi } \\
\text { budidaya kepiting } \\
\text { bakau di Desa } \\
\text { Sumberwaru) }\end{array}$ & 13,7 & $\begin{array}{l}\text { Belum memiliki } \\
\text { wawasan } \\
\text { pengetahuan } \\
\text { (Belum ada } \\
\text { pemahaman tentang } \\
\text { potensi budidaya } \\
\text { kepiting bakau di } \\
\text { Desa Sumberwaru) }\end{array}$ & 40,15 & $\begin{array}{l}\text { Tidak berperilaku } \\
\text { membangun }\end{array}$ & 53,35 & 107.2 \\
\hline 2. & $\begin{array}{ll}\text { Tumbuh } & \text { rasa } \\
\text { kesadaran } & \text { dan } \\
\text { kepedulian } & \\
\text { (Ketertarikan } & \\
\text { responden pada } & \\
\text { usaha budidaya } & \\
\text { kepiting bakau) } & \end{array}$ & 184,4 & $\begin{array}{l}\text { Menguasai } \\
\text { pengetahuan dasar } \\
\text { (Keoptimalan } \\
\text { masyarakat dalam } \\
\text { memanfaatkan } \\
\text { potensi lahan } \\
\text { budidaya kepiting } \\
\text { bakau) }\end{array}$ & 51,15 & $\begin{array}{l}\text { Bersedia terlibat } \\
\text { dalam } \\
\text { pembangunan } \\
\text { (Masyarakat } \\
\text { pernah terlibat } \\
\text { dalam pengelolaan } \\
\text { sumberdaya hutan } \\
\text { bakau yang } \\
\text { diselenggarakan } \\
\text { dari pihak luar } \\
\text { seperti: LSM, } \\
\text { akademisi dan } \\
\text { dinas terkait) }\end{array}$ & 180,4 & 415,9 \\
\hline 3. & $\begin{array}{l}\text { Memupuk semangat } \\
\text { kesadaran dan } \\
\text { kepedulian } \\
\text { (Kemauan untuk } \\
\text { bergabung kelompok } \\
\text { masyarakat nelayan } \\
\text { yang memiliki } \\
\text { kemampuan dalam } \\
\text { budidaya kepiting } \\
\text { bakau) }\end{array}$ & 44,9 & $\begin{array}{l}\text { Mengembangkan } \\
\text { pengetahuan dasar } \\
\text { (Kemampuan } \\
\text { menyerap informasi } \\
\text { dari pihak luar, } \\
\text { seperti: LSM, } \\
\text { akademisi dan Dinas } \\
\text { terkait) }\end{array}$ & 44 & $\begin{array}{l}\text { Berinisiatif untuk } \\
\text { mengambil peran } \\
\text { dalam } \\
\text { pembangunan }\end{array}$ & 53,35 & 142,25 \\
\hline 4. & $\begin{array}{l}\text { Merasa } \\
\text { membutuhkan } \\
\text { kemandirian } \\
\text { (Kemauan untuk } \\
\text { mendapatkan } \\
\text { informasi tentang } \\
\text { pemanfaatan hutan } \\
\text { bakau sebagai lahan } \\
\text { budidaya kepiting } \\
\text { bakau) }\end{array}$ & 53.35 & $\begin{array}{l}\text { Mendalami } \\
\text { pengetahuan pada } \\
\text { tingkat lebih tinggi }\end{array}$ & 51,5 & $\begin{array}{l}\text { Berposisi secara } \\
\text { mandiri untuk } \\
\text { membangun diri } \\
\text { dan lingkungan }\end{array}$ & 53,35 & 158,2 \\
\hline
\end{tabular}

Sumber: Data olahan, 2020

Tabel 2 memperlihatkan bahwa nelayan masih menganut pola pikir linier, dalam pemikiran pada setiap aspek nilai yang meliputi afeksi, kognisi dan konasi akan berbanding lurus satu sama lain. Dimana dari kondisi lapang dinilai rasa kesadaran dan kepedulian (tahapan afektif) masyarakat Desa Sumberwaru terhadap pengembangan potensi budidaya kepiting bakau masih dalam tahap tumbuh, hal ini ditengarai dengan bersedianya masyarakat / $82 \%$ responden dalam 
pengelolaan sumberdaya hutan bakau yang diinisiasi oleh pihak akademisi, Lembaga Swadaya Masyarakat dan dinas terkait. Namun peran keterlibatan masyarakat dinilai masih pasif belum memiliki inisiatif sendiri untuk berkembang.

Tahap kognitif masyarakat desa Sumberwaru dalam mengoptimalkan potensi lahan budidaya kepiting bakau dinilai masih sangat rendah, hal ini ditandai dengan masih rendahnya pemahaman tentang fungsi bakau sebagai kawasan potensial untuk budidaya, sehingga kemampuan untuk mengembangkan dan mendalami tentang pengetahuan dasar tersebut masih belum tampak. Secara khusus sebagian besar (72\% responden) menyatakan tidak paham terhadap fungsi hutan bakau sebagai kawasan potensial untuk budidaya kepiting bakau. Ketidakpahaman sebagian besar responden secara faktual di lapangan ditandai dengan tidak adanya tegakan pohon bakau yang dihasilkan dari proses penanaman oleh masyarakat yang terpelihara secara baik. Sehingga dapat dinilai bahwa daya kognitif masyarakat lokal pada fungsi ekologi dan ekonomi hutan mangrove masih sangat rendah.

Untuk tahapan konatif, masyarakat Desa Sumberwaru sudah berada pada tahap bersedia terlibat dalam pengembangan potensi kawasan bakau, namun belum mencapai tahap berinisiatif mengambil peran dalam pengembangan potensi wilayah untuk budidaya kepiting bakau. Hal ini terlihat pada hasil angket menunjukkan $82 \%$ responden menyatakan terlibat pada kegiatan pengembangan potensi hutan mangrove yang diinisiasi oleh banyak pihak, di antaranya PKK desa Sumberwaru bekerjasama dengan Dinas Perindustrian dan Perdagangan Kabupaten Situbondo, IAI Ibrahimy, Universitas Jember, Serikat Nelayan Indonesia (SNI) dan Majelis Wakil Cabang Nahdlatul Ulama' Kecamatan Banyuputih. Keikut sertaan masyarakat dalam pengembangan potensi budidaya kepiting bakau dinilai masih tergantung pada wadah organisasi yang menaungi, hal ini ditandai dengan belum berlanjutnya program yang sudah diinisiasi pihak luar, dimana salah satunya adalah program yang berjalan hanya pengadaan benih dan proses penanaman, pada tahap selanjutnya, pemeliharaan oleh masyarakat tidak berjalan, sehingga bakau yang telah ditanam tidak bertahan hidup. Hal ini menandakan masyarakat belum memiliki kepahaman yang utuh tentang fungsi dan strategi pengelolaan hutan bakau di kawasan pantai. Dalam situasi seperti itu, tidak ada satu lembaga pemerintah maupun non pemerintah, termasuk pemberi bantuan dana CSR yang mengambil peran asistensi pengelolaan program reforestasi bakau secara berkelanjutan di pesisir Sumberwaru, sehingga bisa dinilai tahap kognitif masyarakat pada pemahaman tentang pengembangan potensi pengembangan budidaya kepiting bakau masih sangat perlu pendampingan secara berkelanjutan, mengingat peran masyarakat lokal menjadi ujung tanduk berhasil atau tidaknya program yang ada.

Sikap masyarakat merupakan salah satu aspek yang berperan penting dalam keberhasilan pengembangan potensi suatu wilayah, dikarenakan sikap merupakan interaksi dan integrasi antara komponen kognisi, afeksi dan konasi. Komponen kognisi berkaitan dengan daya nalar/ pikiran, gagasan/ide dan keyakinan. Sedangkan komponen afeksi berkaitan dengan perasaan dan komponen konasi berkaitan dengan kecenderungan seseorang anggota masyarakat untuk bertingkah laku sesuai sikap.

\section{KESIMPULAN}

Berdasarkan hasil sintesis analisis mengenai kondisi afektif, kognitif dan konatif masyarakat didapatkan tahapan nilai sikap masyarakat Desa Sumberwaru pada tahap kedua afeksinya, begitu pula kondisi kognitif dan konasinya, yang berarti dari kondisi lapang diketahui nilai sikap masyarakat Desa Sumberwaru terhadap pengembangan potensi budidaya kepiting bakau masih dalam tahap tumbuh dan membutuhkan pendampingan yang berkelanjutan oleh pihak yang lebih berkompeten, agar tujuan pembangunan nasional dari pengembangan wilayah berbasis potensi lokal (budidaya kepiting bakau) bisa tercapai dengan optimal. Hal ini sebenarnya mudah dicapai melihat dari potensi wilayah dan regulasi tentang kawasan budidaya sudah baik. Sehingga peran semua lini yang terintegrasi baik dan berkelanjutan amat sangat dibutuhkan dalam pengembangan potensi budidaya kepiting bakau di Desa Sumberwaru.

\section{DAFTAR PUSTAKA}

Avianto, I., Sulistiono, S., \& Setyobudiandi, I. (2013). Karakteristik habitat dan potensi kepiting bakau (Scylla serrata, S. Transquaberica, dan S. olivacea) di hutan mangrove cibako, Sancang, Kabupaten Garut Jawa Barat. AQUASAINS: Jurnal Ilmu Perikanan dan Sumberdaya Perairan, 2(1), 97-106.

Bank Indonesia. (2011). Budidaya kepiting soka. https://www.bi.go.id

Gita, R. S. D., \& Sudarmadji, J. W. (2015). Pengaruh faktor abiotik terhadap keanekaragaman dan kelimpahan kepiting bakau (Scylla spp.) di hutan mangrove blok bedul taman nasional alas purwo. Jurnal Ilmu Dasar, 16(2), 63-68.

Haris, R. (2014). Keanekaragaman vegetasi dan satwa liar hutan mangrove. Bionature, $15(2), 171$ - 121. https://doi.org/10.35580/bionature.v15i2.1558

Hia, P. M. F., \& Hendrarto, B. (2013). Jenis kepiting bakau (Scylla SP.) yang tertangkap di Perairan Labuhan Bahari Belawan Medan. Journal of Management of Aquatic Resources, 2(3), 170-179. https://doi.org/10.14710/marj.v2i3.4212

Karniati, R., Sulistiyono, N., Amelia, R., Slamet, B., Bimantara, Y., \& Basyuni, M. (2021). Mangrove ecosystem in North Sumatran (Indonesia) forests serves as a suitable habitat for mud crabs (Scylla serrata and $S$. olivacea). Biodiversitas Journal of Biological Diversity, 22(3), 1489-1496. https://doi.org/10.13057/biodiv/d220353 
Kusuma, K. R., Safitri, I., \& Warsidah, W. (2021). Keanekaragaman jenis kepiting bakau (Scylla Sp.) di Kuala Kota Singkawang Kalimantan Barat. Jurnal Laut Khatulistiwa, 4(1), 1-9. http://dx.doi.org/10.26418/lkuntan.v4i1.44784

Leoville, A., Lagarde, R., Grondin, H., Faivre, L., Rasoanirina, E., \& Teichert, N. (2021). Influence of environmental conditions on the distribution of burrows of the mud crab, Scylla serrata, in a fringing mangrove ecosystem. Regional Studies in Marine Science, 43, 101684. https://doi.org/10.1016/j.rsma.2021.101684

Lose, I. M. I., Labiro, E., \& Sustri. (2015). Keanekaragaman jenis fauna darat pada kawasan wisata mangrove di Desa Labuan Kecamatan Lage Kabupaten Poso. Warta Rimba, 3(2), 118 - 123.

Mahfud, M. Z., Sudarmadji, \& Subchan, W. (2017). Pengaruh faktor lingkungan terhadap relative fitness dan distribusi spasial kepiting bakau (Scyllaspp) di Hutan Mangrove Blok Bedul Sogoro Anak Taman Nasional Alas Purwo. Jurnal IImu Dasar, 18(2), 65 - 72. https://doi.org/10.19184/jid.v18i2.3909

Pambudi, D. S., Budiharjo, A., \& Sunarto, S. (2019). Kelimpahan dan keanekaragaman kepiting bakau (Scylla spp.) di kawasan hutan bakau Pasar Banggil, Rembang. Jurnal Penelitian Perikanan Indonesia, 25(2), 93-102. http://dx.doi.org/10.15578/jppi.25.2.2019.93-102

Parni, B., Prianto, E., Hasbi, M., \& Hendrizal, A. (2020). Pengembangan budidaya kepiting bakau (Scylla sp) sistem silvofishery untuk melestarikan hutan bakau di kabupaten Kepulauan Meranti Provinsi Riau. Jurnal Kebijakan Perikanan Indonesia, 12(2), 101-108. http://dx.doi.org/10.15578/jkpi.12.2.2020.101-108

Putriningtias, A., Faisal, T. M., Komariyah, S., Bahri, S., \& Akbar, H. (2019). Keanekaragaman jenis kepiting di ekosistem hutan mangrove Kuala Langsa, Kota Langsa, Aceh. Jurnal Biologi Tropis, 19(1), 101 - 107. http://dx.doi.org/10.29303/jbt.v19i1.1074

Rahman, M. Z., \& Pansyah, D. (2019). Pemberdayaan ekonomi masyarakat pesisir melalui pemanfaatan hutan mangrove untuk budidaya kepiting bakau Desa Eat Mayang Sekotong Timur Lombok Barat. Geography: Jurnal Kajian, Penelitian dan Pengembangan Pendidikan, 7(2), 1-10. https://doi.org/10.31764/geography.v7i2.1426

Rangka, N. A. (2007). Status usaha kepiting bakau ditinjau dari aspek peluang dan prospeknya. Neptunus, 14(1), 90100.

Rizaldi, D. R., \& Utami, E. (2015). Kelimpahan kepiting bakau (Scylla sp) di Perairan Muara Tebo Sungailiat. Akuatik, 9(2), 1-14.

Ruscoe, I. M., Shelley, C. C., \& Williams, G. R. (2004). The combined effects of temperature and salinity on growth and survival of juvenile mud crabs (Scylla serrata Forskål). Aquaculture, 238(1-4), 239-247. https://doi.org/10.1016/j.aquaculture.2004.05.030

Sangari, J. R., \& Toloh, B. H. (2015). Potensi pertumbuhan kepiting bakau (Scylla serrata) di perairan Pulau Mantehage, Taman Nasional Bunaken Sulawesi Utara. Jurnal IImiah Platax, 3(1), 1-9.

Sara, L., Aguilar, R. O., Ingles, J. A., \& Laureta, L. V. (2014). Habitat characteristics and relative abundance of the mud crab Scylla serrata (Forskål, 1775) in Lawele Bay, Southeast Sulawesi, Indonesia. Ege Journal of Fisheries and Aquatic Sciences, 31(1), 11-18.

Sulistyani. (2004). Kemitraan dan model-model pemberdayaan. Yogyakarta : Gava Media.

Syahrera, B., Purnama, D., \& Zamdial, Z. (2016). Asosiasi kelimpahan kepiting bakau dengan keberadaan jenis vegetasi mangrove Kelurahan Sumber Jaya Kecamatan Kampung Melayu Kota Bengkulu. Jurnal Enggano, 1(2), 47-55.

Wahab. (2017). Analisis potensi budidaya kepiting bakau di Desa Sumberwaru, Kecamatan Banyuputih, Kabupaten Situbondo.

Widyastuti, E. (2017). Keanekaragaman kepiting pada ekosistem mangrove di perairan Lingga Utara dan sekitarnya, Kepulauan Riau. Zoo Indonesia, 25(1), 22-32.

Wijaya, N. I., \& Yulianda, F. (2017). Model pengelolaan kepiting bakau untuk kelestarian habitat mangrove di Taman Nasional Kutai Provinsi Kalimantan Timur. Jurnal Manusia \& Lingkungan, 24(2), 55-65. https://doi.org/10.24843/blje.2019.v19.i01.p01

Zulfiqri, M., Mardhia, D., Syafikri, D., \& Bachri, S. (2020). Analisis Kelimpahan Kepiting Bakau (Scylla Sp.) di Kawasan Hutan Mangrove Kecamatan Alas Barat Kabupaten Sumbawa. Indonesian Journal of Applied Science and Technology, 1(1), 29-38. 